How to Suppress Women's Writing 
BOOK FORTY-THREE

Louann Atkins Temple Women \& Culture Series

Books about women and families, and their changing role in society 


\section{How to Suppress}

Women's Writing

$* * *$

\section{Joanna Russ}

With a new foreword by

JESSA CRISPIN 
The Louann Atkins Temple Women \& Culture Series is supported by Allison, Doug, Taylor, and Andy Bacon; Margaret, Lawrence, Will, John, and Annie Temple; Larry Temple; The Temple-Inland Foundation; and the National Endowment for the Humanities.

Grateful acknowledgment is made to W. W. Norton and Company for permission to reprint lines from a poem by Adrienne Rich, originally published in her Poems: Selected and New, 1950-1974.

Copyright (C) 1983 by Joanna Russ

New edition (C) 2018 by the University of

Texas Press

Foreword to the new edition (C) 2018 by Jessa Crispin

All rights reserved

Printed in the United States of America

Requests for permission to reproduce material

from this work should be sent to:

$$
\begin{aligned}
& \text { Permissions } \\
& \text { University of Texas Press } \\
& \text { P.O. Box } 7819 \\
& \text { Austin, TX } 78713-7819 \\
& \text { utpress.utexas.edu/rp-form }
\end{aligned}
$$

The paper used in this book meets the minimum requirements of ANSI/NISO Z39.48-1992 (R1997) (Permanence of Paper).@

Book design by Lindsay Starr Typesetting by Integrated Composition Systems
Names: Russ, Joanna, 1937-2011, author. | Crispin, Jessa, writer of supplementary textual content.

Title: How to suppress women's writing / Joanna Russ ; with a new foreword by Jessa Crispin.

Description: New edition. | Austin : University of Texas Press, 2018.| Includes bibliographical references and index.

Identifiers: LCCN 2017048972 ISBN 978-1-4773-1625-2 (pbk. : alk. paper) ISBN 978-1-4773-1628-3 (library e-book)

ISBN 978-1-4773-1629-o (nonlibrary e-book)

Subjects: LCSH: Women authors, English-History and criticism. | Women authors, AmericanHistory and criticism. | Women in literature-History and criticism. | Authorship-Sex differences. | Censorship.

Classification: LCC PN471 .R87 2018| DDC 809/.89287-dc23

LC record available at https://lccn.loc .gov/2017048972

doi:10.756o/316252 
This book is dedicated to my students. 
THIS PAGE INTENTIONALLY LEFT BLANK 